\title{
Artistic Originality of Children's Poetry of Dzhaminat Kerimova
}

\author{
Akamov Abusup'yan Tatarkhanovich ${ }^{1}$, Mukhamedova Fatyma Khamzaevna ${ }^{2}$, Alkhlavova Inna \\ Khumkerkhanovna ${ }^{3} \&$ Bekeeva Aygul Muratovna ${ }^{4}$ \\ ${ }^{1}$ Literature Department, Institute of Language, Literature and Arts n. a. G. Tsadasa, Dagestan Scientific Centre, \\ RAS, Russian Federation \\ ${ }^{2}$ The Centre of Study of R. Gamzatov's Literary Heritage, Institute of Language, Literature and Arts n. a. G. \\ Tsadasa, Dagestan Scientific Centre, RAS, Russian Federation \\ ${ }^{3}$ Literature Department, Institute of Language, Literature and Arts n. a. G. Tsadasa, Dagestan Scientific Centre, \\ RAS, Russian Federation \\ ${ }^{4}$ Institute of Language, Literature and Arts n. a. G. Tsadasa, Dagestan Scientific Centre, RAS, Russian Federation \\ Correspondence: Bekeeva Aygul Muratovna, Institute of Language, Literature and the Arts n. a. G. Tsadasa of the \\ Russian Academy of Sciences, 367000, Makhachkala, Republic of Dagestan, The Russian Federation, Tel: 7-(929)- \\ 929-17-12. (Makhachkala, Russia). E-mail: bekeeva-92@mail.ru
}

Received: March 11, 2019; Accepted: March 23, 2019; Published: March 30, 2019

\begin{abstract}
In this article, the poems of the famous modern Kumyk poet Dzhaminat Kerimova for children of preschool and school age are analyzed. The artistic originality of poetic texts is considered, their comparative analysis is given. There are a thematic range, figurative system and poetics of the works in the focus of attention. In the course of the study, we have found that the works of children's lyrics of Dzh. Kerimova are various in the themes and intonation. The deep penetration into the wonderful world of the childhood and transfer in poetic texts of a live children's view of surrounding reality are observed. The author's poems are original, full of national color. It is established that the lyrical expressions are profound, edification is reflected.
\end{abstract}

Keywords: Dzhaminat Kerimova, soviet period, Dagestan children's literature, stylistic devices and expressive means

\section{Introduction}

It is known that Russian children's literature is developing as a "multinational" phenomenon. Multinational peoples inhabiting the territory of the Russian Federation acquired their own traditions of children's literature (it happened based on national folklore). In contrast to the foreign literature, our national literature is united based on the Russian language, because children of different peoples learn Russian language in addition to their native one. Thus, the common historical fate of peoples, close interaction of cultures, the language of international communication (Russian) unites the national literature of the peoples of Russia. The experience of Russian literature enriched the North Caucasian literature with themes, images, motifs, genres, and poetics. Literature of the peoples of the North Caucasus differs from Russian literature in national style and national specifics. It takes into account, first, the mentality of the people, which determines the special structure of each of the works of a writer, poet. When writing their works, the authors rely primarily on the knowledge of the real life of their people and the nature of the Caucasus, their social structure and spiritual culture, highlighting in it not so much religion as mentality, mountain etiquette and other ethnic foundations of the culture of their people. So, for clarity, let us turn to the works for children about the nature of Russian and North Caucasian (specifically: Kumyk) authors.

Such well-known poets, like Mukhammad Atabaev, Badrutdin Magomedov, Akhmed Dzhachaev, Sheit-Khanum Alisheva, Atav Ataev, Abdul-Kerim Zalimkhanov, Bagautdin Adzhiev, etc, represent modern Kumyk poetry. Relatively young authors are Musa Shikhavov, Sup'yanat Mamaeva, Kazim Kazimov, Gebek Konakbaev, Nabiulla Magomedov, Zuleykha Atakishieva, Khamisat Khizrieva and many others. Kumyk poetry grows and develops. In this regard, there are new names, the work of which attracts the attention of researchers. Among the modern Kumyk poets, we can point out Dzhaminat Kerimova too. In addition, about her poetry for the children is this paper. 


\subsection{A Difficult Way of Dzhaminat Kerimova in Getting Education}

Talented Kumyk poet, translator Dzhaminat Kerimova takes a worthy place in Dagestan literature. She was born in Tarki village of Makhachkala in 1948. Dzh. Kerimova was the seventh child in the family. The childhood of the poet was different from the childhood of her coevals. The reason for this was a serious illness, a disease that bound a six-year-old girl, depriving her of the opportunity to move independently. The doctors diagnosed myopathy, which sounded like a death sentence. Despite it, the hope for recovery did not die away neither at the girl, nor her parents who loved and cared for her. She went to school at the age of ten (her parents took her to school, because she could not move on her own). Dzhaminat Kerimova was fond of study from the first days... After four years, she continued it distantly.

During her school years, Dzh. Kerimova began to reveal the talent of the poet. Teachers noticed it and supported the little girl in her poetic principles.

In 1971, after graduation (despite the illness), Dzhaminat Kerimova entered the Russian-Dagestan department of the faculty of Philology of Dagestan state University n. a. V. I. Lenin. She studied in absentia; teachers took exams at her home. Dzh. Kerimova loved literature and read a lot. In 1967, her first poem written in the native Kumyk language was published in the newspaper "The way of Lenin" ("Leninni Yolu"). Later - in different Dagestan book publishing houses.

For the courage with which she treated her illness, for the poetry of her poems, for the fact that she was able to make her life filled with high meaning, Dagestan people admire Dzh. Kerimova, love and respect her. Kerimova's poetry strikes readers with abundance of major notes, optimistic mood. All her poems are filled with immeasurable love for people, nature, Homeland. In the lyrical lines of the Kumyk poet, we observe an amazing femininity, melody. Poetic creations of the author are filled with reflections and meditations. They are imbued with expectation and a sense of human happiness. Despite the inability to move independently, Kerimova, flushed with happiness, did not cease to enjoy life to enjoy life. She loved life dearly, as a priceless gift of fate. Very often guests visited the house of the poet: poets, novelists, playwrights, journalists and even strangers.

\subsection{Children's Poetry in the Kumyk Literature}

There is no doubt that children's literature of different peoples has a big interest for the literary critics. Researching the theme of the poetry of Dz. Kerimova, we appealed to the next works: Lojter S. M. Russian children's literature of the XX century and children's folklore: problems of interaction, 2002; Gul'cev A. I. Modern children's literature of Great Britain: historical and cultural aspects, 2002; Valeev M. Kh. Tatar children's literature and children's book of the end of XX century (1980-2000); Lyamova B. Kh. Formation and development of Adygei children's literature, 2013.

The formation and development of literature for children Dagestan researchers refer to the beginning of the XX century. However, in the work "The Emergence and development of Kumyk children's poetry (the end of XIXfirst half of XX century)" N. K. Adzhamatova analyzing the works of M. Osmanov, A. Akaev, M. Alibekov notices, "Kumyk children's literature began its independent development in the pre-revolutionary years, when it was still part of the "adult" literature" (Adzhamatova, 1994, p. 16). In the post-revolutionary period the development of poetry for children continued in the works of Kumyk authors T. Beybulatov ("Collection of poems and songs", 1926), A.-P. Salavatov ("The Beginning", 1928, "For the children", 1930). The Soviet period of development of the Dagestan children's literature characterizes by F. Kh. Mukhamedova: "The children's poetry of the $60-80^{\text {th }}$ took one of the leading places in the Dagestan Soviet literature. The multinational creativity of Dagestan poets is presented in numerous collections, published in large editions in local and central publishing houses and received good reviews from critics. Children's poetry continues to develop in the track with all Dagestan Soviet literature, striving for new creative achievements" (Mukhamedova, 2001, p. 116-117). During this period, poems for children write such Kumyk poets as M. Atabaev, B. Magomedov, V. Ataev, A. Dzhachaev, B. Adzhiev, A. Ataev, I. Asekov, A. Medzhidov, Sh.-Kh. Alisheva, S. Mamaeva, Dzh. Kerimova etc.

The literary heritage of Dzh. Kerimova - one of the talented Kumyk poets of the late XX - early XXI centuries remains unexplored in its entirety. There are separate articles published in the newspapers "The Truth Of Dagestan" ("Dagestanskaya Pravda"), "The Woman Of Dagestan" ("Zhentshina Dagestana"), "News of Makhachkala" ("Makhachkalinskiye Izvestiya"), "Companion" ("Yoldash"), "Youth of Dagestan" ("Molodezh' Dagestana"), "The Komsomol Member of Dagestan" ("Komsomolets Dagestana"). These papers are devoted to individual aspects of life and works of Dzhaminat Kerimova. In particular, about the work Dzh. Karimova wrote R. Gamzatov, M. Atabayev, K. Abukov, F. Aliyeva, A. Adzhiev, A.-K. Abdullatipov, Z. Akavov, B. Gadzhiev, D. Kardashev, etc. 


\section{Relevance of a Subject of Research}

The relevance of the research topic is due to the need to create a complete picture of the children's poetry of Dzh. Kerimova. In our opinion, the study of this topic will allow us to fill the lack in the study of modern Kumyk children's poetry, thus enriching not only Kumyk, but also Dagestan literary criticism.

\section{The Purpose}

The Purpose of our research is the identification of an art originality of poems for children of Dzh. Kerimova. In this regard the following tasks are set: to track style features of children's poetry; to define a role of children's lyrics of Dzh. Kerimova in terms of her esthetic, educational functions. The poetic texts for children of the studied poet, specifics of style and language features of her children's lyrics are for the first time are characterized in this article.

\section{Methods}

The authors of this article used descriptive and comparative methods, having taken as a basis the texts in the original language. The method of structuralism helps to reveal features of the national text, promotes "interpretation" of the author's thought.

\section{Discussion}

\subsection{The Theme of Patriotism in the Poems for Children}

The theme of patriotism has a special sound in the poems of Dzhaminat Kerimova. It is expressed in such poems as "I am a daughter of my nation" ("Men ehlimni k"yzyman"), "Duty" ("Borch"), "A lonely rock" ("Ajry yar"), "My native village" ("Meni aziz yurtum"), "Russia" ("Rossiya"), "There are a lot of sad peoples in the world" ("Bu dyun'yada zarly halk"lar az tyugyul"), "Moscow is speaking" ("Syojlej Moskva"), "A Young Officer" ("Oficer yash"), "The Song" ("Jyr"), "Your country is the USSR" ("Ehling SSSR"), "My wealth" ("Bajlyg"ym"), "My destiny" ("K"ysmatym”), "My people" ("Halk"ym"), "I'd say" (“Ajtar ehdim"), "Grief of mountain" ("Tavnu derti”) etc. In these poems, Homeland is considered as an absolute value, a Holy substance. The style of the works of the poet is characterized by a high syllable and enthusiastic pathos. The author is equally attached to the big (Russia) and small (Tarki - an ancient villiage in Dagestan, now an urban village $3 \mathrm{~km}$ far from the railway station of Makhachkala) homeland.

The poems devoted to the Homeland, reflect the poet's experiences, her reasoning, thoughts. The patriotic theme in the poetry of Dzh. Kerimova sounds in civil lyrics, poems, works for children, quatrains. Love, honor, respect, admiration to Tarki are reflected in the poem "Lonely rock" "Ajry yar"):

Ajry yarym, Ajry yar,

Gichchiden ayavlu yar,

Ajry yarg"a ajrycha

Yuregimde syuyuv bar (Kerimova, 1984, p. 6).

My Lonely rock, Lonely rock,

Since childhood, my native rock,

Separate to the lonely rock

There is love in my heart.

\section{(Subscript translation here and further by the authors of the article)}

The stylistic devices and expressive means used to characterize the beauty of native places' nature are comparisons, personifications, metaphors, the metaphorical epithets: "youth high throne of my Lonely rock, a Lonely rock" ("yashlyk" ny bijik tahy Ajry yarym, Ajry yar"), "my native village, native village, my Golden cradle" ("ata yurtum, ata yurt, altyn beshigim meni"), "my native village, native village, my Golden nest, my cradle" ("ata yurtum, ata yurt, altyn uyam, g'ajlegim"), "I grew up in the arms of the Motherland, laughing and frolicking" ("Vatanny $k^{\prime \prime} u c h a g " y n d a$ o'sdyum men kyulep-ojnap"), "my country is my wealth, it has no price and no equal" ("Vatan meni bajlyg"ym bag'asy yok", tengi yok").

The image of the small Motherland is developed in the poems of almost every Kumyk poet. Patriotism is a concept that has its own meaning for every person. The theme of patriotism sounds also in poems by A. Adzhiyev, A. 
Medzhidov, A. Dzhachayev, V. Atayev etc. Let us pay attention to the poem "We Will Protect Our Homeland" ("Ehlibizni yak"larbyz", 2018) of S. Mamayeva where this subject is also reflected:

Gyoz alda bajrak",

Igitler k"ak"g"an.

Yurekde syuyuv,

Vatang"a bak"g"an (Mamaeva, 2018, p. 130).

There is a flag before the eyes,

Which do the heroes set up.

There is love in our hearts,

Which is turned for our Homeland.

Another Kumyk poet A. A. Adzhamatov expresses his love for the Motherland not only in the description of its nature, but also in the admiration of famous personalities who have made a huge contribution to the political history and cultural life of the Republic Dagestan: "Double gift to Lenin" ("Leninge ehki savg"at"), "On a small Lermontov Street" ("Lermontovnu gichchi oramynda"), "To Nikolay Tikhonov" ("Nikolaj Tihonovg"a"), etc. These works call to the formation in children a sense of respect and recognition for historical figures of our past; they expand the views of young readers about those talented individuals who have made an invaluable contribution to the cultural and spiritual development of our region and the country as a whole.

For A. A. Medzhidov Motherland is associated with the native land, with the life of ordinary people. The image of the unity of nature, everyday life and soul are patriotic features of the poetry of A. A. Medzhidov. This unity is demonstrated in the poem "The Smell of the Village" ("Yurtnu ijisi"). Actually, in the life of the Dagestan people sheds were built since ancient time and there in national ovens ("koryuks") women baked bread. They fired up a furnace and baked in turn. Moreover, people cured herbs' leaves, among of which plantain, thyme, viburnum and cumin. They were used in making some tea and for the Caucasus cooking:

Bir-birine k"oshulsa

Baryny da ijisi,

Nechik bola, kim bile?

Men bilemen, men bile,

Bizin gyotermebizden

Yurtnu ijisi gele (Medzhidov, 1987, p. 10).

So, one of the main motifs of the studied topic is the readiness to "give life" for the sake of the Motherland. Symbolic image of a small homeland of the poet is "the rock", because the village is located on the mountain "Tarki - Tau". There is a poetization of the stone: Kerimova compares residents of Tarki with the stone:

Tash topurak", tash u'jler,

Betaul tashdan tolg"an,

Munda yashav k"urg"anlar

Tash jimik k"atty bolg"an (Kerimova, 1986, p. 12).

Stone land, stone houses,

The village is full of stones,

Those who settled here

Have become strong as the stone.

About love, admiration, respect and devotion to her people the poet is narrated in the work "My people" ("Halk"ym"). 
Bitmes hazna yureginde halk"ymny,

K"umuk" busa,

Adillidir g'amang"a,

Yahshylag"a yuregimni berermen,

Tek k"umuk" dep ajtma bolman yamang"a (Kerimova, p. 19).

Wealth will not end in the heart of my people,

If the Kumyk,

That will be fair constantly,

I will give my heart for good people,

However, a bad person I will not be able even to call a Kumyk.

In the following lyrical text, the poet declares herself "the daughter of her people". Here we see the author's indissoluble connection with the people, her devotion and respect for him:

Men halk"ymny k"yzyman,

Halk" meni esim,

Dazudag"y dazuchudaj

Sak" tursun esim (Kerimova, 1985, p. 4).

I am the daughter of my people,

My people is a master mine,

On the border the border guard

Let my mind be vigilant.

The homeland for Kerimova is a mother, a native village, people. Love for the Homeland of the poet manifests itself through a love of nature. Reading her poems, the reader unwittingly presents landscape sketches: the trills of the Nightingale sound ("gichchinev k"ush byulbyul de alaj jyrlaj syuyunyup"); it is heard as, frolicking and playing, water flows from a spring ("bulak" ojnaj, sharyllaj"); watch the dawn in Tarki and the awakening of the mountains ("Targ"uda tang shek berdi"; "tyuesyrtly tavlarym mahmarly tyoshyun gerdi") etc. The author inspires the nature of his native land, giving it human characters and features, because it is alive, different and graceful. This is the peculiarity of the landscape sketches of the poet.

\subsection{The Concept of "Mother - Homeland" in Russian and Kumyk Children's Poetry}

The theme of "Motherland-Russia" is one of the traditional themes of Russian and Dagestan poetry, which is characterized by stable shaped parallels: Russia - mother, Russia - defender, Russia - hope, etc. Traditional is the connection of the image of Russia with the images of "road", "distances", "space", "wind" and "songs". These concepts we meet in the poetry of Dzh. Kerimova too. For instance, "Russia! In many songs sounded your name" ("Rossiya! Kyop jyrlarda jyrlang"an seni atyng"); "Russia! - having pronounced it, the Russian field, the Russian river, the Russian lake appear before my eyes" ("Rossiya! - dep ajtsam, gele gyoz alg"a rus avlak"lar, rus o'zenler, rus kyoller"), "Russia! - having heard your name, my step becomes wider" ("Rossiya! - dep, seni atyng chalynsa, abatym da meni ehrkin alyna") etc. The perception of the Motherland and, accordingly, the image of Russia in each poet are peculiar, which is reflected in the nature of the nominations and their choice.

We meet this parallel in Russian literature too. If Dzh. Kerimova has an abstract imagery of the homeland, the Russian poet V. Tushnova concretizes it:

"They say: Russia"

They say Russia... 
Is the rivers and birches...

But I see your hands,

knobby hands,

tough.

Hands, shriveled from washing,

Wet from bitter tears,

Rocked, swaddled,

Blessed to the victory.

$<\ldots>$ Your hands are kind,

Your hands are beautiful,

My Mother, Russia!

(Veronika Tushnova)

"Vot govoryat: Rossiya"

Vot govoryat: Rossiya...

Rechen'ki da berezki...

A ya tvoi ruki vizhu,

uzlovatye ruki,

zhestkie.

Ruki, ot stirki smorshchennye,

slezami gor'kimi smochennye,

kachavshie, pelenavshie,

na pobedu blagoslovlyavshie.

$<\ldots>$ Dobrye tvoi ruki,

prekrasnye tvoi ruki,

mater' moya, Rossiya!

This poem has something in common with the poem by Dzh. Kerimova, "My wealth" ("Bajlyg"ym"). There is a figurative parallel "Homeland - Mother". As we know, the Mother is the center of the ideal space of life of people. The archaic metaphor (mythologeme) of the Motherland defines the figurative structure of the above-mentioned poems. Therefore, both authors not just compare, they also identify the homeland with the woman, mother.

For Russian mentality, key characteristics, which we can call spirituality, creativity, imagery and soil, true to form comparison the Homeland with Mother. Russian proverb "Native land is a mother, strange one is a stepmother" is the evidence of the rooting of the image of the Motherland in the national mentality. This same phenomenon is observed in Kumyk Proverbs, for example, "The land of the Motherland is invaluable like mother's milk" ("Vatanyngny toprag" $y$ - ana syutyudej aziz").

The archetype of the Mother is embodied, According to V. N. Telia, "in the concept of "homeland", which is manifested in those of its characteristics, which are characteristic of the features of a caring mother" (Teliya, 1999, p. 470). Thus, in the poem "They say: Russia" the key symbol is the "mother's hands" that can give warmth, affection, kindness despite all the trials of life.

Homeland, native land in the national mentality is characterized as a nurse, intercessor, capable of compassion, patience, suffering, vulnerable and emotional. In relation to the Homeland, every Russian, regardless of the national mentality, feels the same feelings that a child feels for his mother.

Thus, we can conclude that the figurative comparison of the Motherland and the Mother occupies an important place in all national mentalities of the Russian Federation. The relations between a person and the Motherland are similar to the relations of close, native to each other personalities; they do not depend on the economy, politics or 
ideology. Homeland is understood as a person who is for each person a source of life, the ideal of love, care and intercession.

The feather grass is sleeping. Dear plain,

In addition, the wormwood of lead freshness too.

No homeland other

Will not pour warmth into my breast.

(S. Esenin)

Spit kovyl'. Ravnina dorogaya,

I svincovoj svezhesti polyn'.

Nikakaya rodina drugaya

Ne vol'et mne v grud' moyu teplyn'.

The theme of the Motherland becomes an important theme for many authors. In the works of S. A. Yesenin it is especially fully revealed through the image of the village. The poet always speaks with warmth and awe about Russian antiquity, about nature and everything that is associated with his childhood. In spite of everything, he loves his Homeland, devotes many poems to it.

In his work, he gives it to the village "Russian origin", because there are preserved culture and traditions, harmony with nature. Therefore, peasant life, and nature become central themes of his poems. He was able not only to preserve the boundless love for the Motherland, but also to convey it to his readers through clear images of the village and nature.

We see that Dzh. Kerimova, like many other Kumyk and Russian poets, correlates with the image of the Mother:

Men Vatanny k"yzyman,

Vatanym mag"a ana,

Anasy k"yzynadaj

Vatan mag"a inana (Kerimova, 1986, p. 67).

I am the daughter of the country,

For me, the Homeland is the mother,

Like the mother of her daughter

Homeland believes me.

Thus, having considered the civil lyrics of Dzh. Kerimova and having done a philological analysis of the works, we concluded that the Motherland appears in poems in different images. Mostly Kerimova in her lyrics used the word "Motherland" because the homeland for humanity, as the mother to the baby, it is everything.

Dzhaminat Kerimova published two small poetic collections for children: "Sunny Watches" ("Gyunsag'at", 1985) and "Winner-girl" ("Yarysh alg"an $k " y z ", 1989)$. In her poems, addressed to small readers, the notes of edification sound moderately. The Russian literary critic V. G. Belinskiy wrote, "The main thing - as little as possible morals, chatter: the adults do not like them, while children just hate, as well as everything boring, all dry and dead" (Belinskij, Chernyshevskij \& Dobrolyubov, 1954, p. 84).

The innovation of the Dagestan children's poetry of the Soviet period is the appearance of the new hero - the pioneer, an image of the ideal Soviet child, a school student who is presented also in the poem "Song by Pioneers ("Pionerleni jyry") by Dzh. Kerimova. The work reflects the ideological atmosphere of Soviet life and appears as a song praising patriotism. The subject of admiration and pride of children is the pioneer red tie. The poet encourages children-pioneers to be always ahead, because the Motherland chose them as pioneers. This poem raises the theme of world peace. The appeal to the fact that it is necessary to live and not to allow thoughts of war sounds:

Yabushuv yuryute halk", 
Dav bolmasyn dep dag"y!

K"astybyz - k"urdash ehtmek

Bar yashny dyun'yadag"y (Kerimova, 1989, p. 3).

People are fighting for something,

Therefore, there would be no war!

Our intention is to make friends

With all the world's children.

The poem comes to the end with glorification of Komsomol - it is the so-called "elder brother" of pioneers directing to a right way and urging to be always ahead.

The works "My Native Village" ("Ata yurtum", 1989), "The Soviet army" ("Sovet Armiya", 1989), "My brother serves the army" ("Amalym armiyada", 1989), "The song of the world" ("Parahatlyk"ny jyry", 1989) are imbued with patriotic feeling. They open a subject of education of the young generation; instill in them the love of the Motherland, call for peace and friendship:

Bizin Vatan - gyozel bav,

Balk"ytag"an yashavnu,

Taryk" tyugyul bizge dav,

Biz bashlamajbyz davnu! (Kerimova, 1989, p.7)

Our Homeland is a beautiful garden,

Filling with bright paints life,

We do not need war,

We do not begin war!

\subsection{Analysis of Poems about the Nature}

The literature even at early stages of its development made a landscape one of the most active means of art display of the world because "the nature for poetry is it's the second "ego", a mirror in which own shape is more clearly learned" (Alkhlavova, 2018, p. 445). Children's landscape lyrics "uses the power of imagination inherent in children, the ability to animate the phenomena of nature, fantastic rethinking of everything around, which makes the world colorful and multi-sounding. It is valuable because it is addressed to the feelings, the inner world of the child, and simultaneously it is complicated because it requires a spiritual response, setting a certain poetic wave" (Mukhamedova, 2001, p. 123).

For young readers, the artistic world created by the poet is presented in different forms and colors. Her poetry is emotional and attracts with their expression. Dzhaminat Kerimova conveys in her poems joy, admiration, surprise, kindness and responsiveness. Therefore, unexpected poetic images, expressive means used by the author, help to recreate the picture of the magical beauty of the long-awaited summer rain, which brought joy to adults and children, and to each flower and leaf:

Yangurdan toyup bolmaj,

Yapyrak"lar hars ura,

Syuyunmekden terekler

Bijip jiberme tura (Kerimova, 1989, p. 19).

Because they can't get enough of the rain,

Leaves clap,

Trees with joy

Almost start dancing. 
A. Medzhidov in his poem "Rain, rain, drizzle" ("Yangur, yangur, sebele") used bright and unusual poetic images and tropes. So, using the different forms of imperative verbs, the author gives "rain" properties of a living person:

Yangur, yangur, sebele,

K"abak"lany tyobele,

Habizhajny chajyndyr,

Pastanlany tok"ala,

K"apustany kirindir,

Pamadurnu syuyundyur (Medzhidov, 1987, p. 70).

Rain, rain, drizzle,

Beat the pumpkin,

Rinse the corn,

Beat the melon,

Cabbage bathe,

Make the tomato happy.

Both poetic texts are dedicated to the summer rain, filled with a sense of joy and admiration. Very expressive images of rain and vegetation, formed based on associative-semantic connection of lexical means (highlighted in the poetic texts). All expressive means are aimed at creating a positive tone and focused on the key images and play, in our opinion, an auxiliary role. Verbs make narrative dynamic; thanks to them, a small reader sees drawn before his mental gaze pictures. Assonance and alliteration transmit emotional mood of the poet.

Each poet depicts rain according to his individual vision of nature. It is a poetic reflection of the author's attitude. Therefore, Dzhaminat Kerimova represents it as "rain-woman"- Medzhidov as "rain-hellion", which indicates gender stereotypes. It is worth noting that as in the folk-poetical works, both authors successfully turn to anthropomorphism, personification of nature.

As well as in folk-poetic creativity, both authors successfully address to anthropomorphism, personification of the nature. Of particular interest is the poem "The Raven" (" $K$ " $\arg { }^{\prime} " a$ "). "The richness of children's Kumyk poetry lies in the richness of its language. Learning the language, our children learn the culture of their native land, learn about its features, learn to love and respect what surrounds them" (Khadzhakaeva, 2018, p. 459]. Here we observe the play of words and sounds. For Dzh. Kerimova a sound bears independent value. A phoneme is not just a part of a word it is a semantic kernel.

In the semantic-syntactic relations in the poems of Dzh. Kerimova can enter words corresponding to each other with a set of vowels (vocal combinations) and consonant sounds (consonant combinations). In the poem "The Raven" (" $K$ " $\arg " a$ "), consisting from 22 strophes, the sound [k"] dominates. We meet it 132 times during the reading of the poem. The sound $\left[\mathrm{g}^{\prime \prime}\right]-75$ times. These two sounds convey a figurative picture of what is happening. The poet plays, experiments with sounds, and thus arouses interest in the little reader:

K"abak"g"a k"onup, chyrg"a,

«K"ak"!» dep k"ychyra k"arg"a.

K"arg"a ne zat ashasyn -

Sav dyun'ya tolg"an k"arg"a.

Meni gichchi amajym

Alyp legenni k"ag"a.

- K"ak"ma! - dejmen.

- K"ag"aman!

“K"ak"'” dep ajta chy k"arg"a (Kerimova, 1989, p. 24). 
Sitting on the gate, on the fence,

"CAW!" is cawing the Raven.

Than what should eat the crow -

The whole world is full of snow.

My younger brother

Is knocking on the copper basin.

- Don't knock! - I say.

- I will knock!

[Because] "Knock" says the crow.

The author skillfully uses such means of artistic expression as onomatopoeia (one of the phonetic resources of the language). There is no meaning in the crow's croaking " $k$ " $a k$ "?" ("caw"). Usually, it is a kind of alarm sounds or just a reference to his relatives. However, the lyrical hero understands this differently, because in the Kumyk language there is such a verb of the imperative mood - " $k$ " $a k^{\prime \prime \prime}$, which means, "knock". The phenomenon of homonymy helps to convey what is happening. This poem uses the following homoforms: " $k$ " $a r g$ " $a$ " - it is a raven, a word-combination " $k$ "araj $k$ "arg" $a$ " - "is looking on the snow". Thus, using the play of words and sounds, focusing on the laws of children's thinking and perception, Dzhaminat Kerimova wrote the interesting and unusualsounding poem "The Raven" (" $K$ " $a r g " a$ ").

It should be pointed out, that such poems for the children are a widespread phenomenon.

Therefore, for example, we can notice it in the poem "White-white Snow" ("Ap-ak" $k$ " $a r$ ", 2018) of a modern Kumyk poetess Sup'yanat Mamaeva. The composition includes 3 strophes. Here the sound [k"] dominates too. We meet it 23 times, and the sound [g"] is used 9 times. The children's attention attracts "colorful" antonymic pair with the prepositional intensifying particle "up" (here the participle "up" gives the meaning "a snow of crystal white" ("ap-ak" $k$ "ar"). The participle "k"ap" means that the craw has rich black colour (" $k$ "ap- $k$ "ara $k$ "arg" $a$ "). Here the author also used the play of words and sounds, known as homomorphism.

Abzar tolg"an ak" k"arg"a

K"ong"an k"ap-k"ara k"arg"a.

Tez-tez get shundan, k"arg"a,

Tijme bizin ak" k"arg"a (Mammaeva, 2018, p. 132).

On the yard filling with white snow

A black Raven flew.

Quick, quick, get out of here, crow,

Do not touch our white snow.

Distinguish feature of the Kumyk poems about the nature is depiction of Caucasus picturesque nature (mountains, rivers, Caspian Sea, sand mountain Sarykum). In Russian poetic texts, we observe a little bit another picture of nature: birch, bird cherry, groove, fields, forests, hills, etc.

"A white birch"

A white birch

Is under my window

Is covered with the snow,

Just like with the silver.

On the furry branches

By the snowy border

The bunches blossomed out 
With the white fringe.

In addition, there is a birch

In sleepy silence,

Moreover, snowflakes are burning

in the golden fire.

And the sunset lazily,

Passing by around,

It sprinkles new silver

On birch branches.

(S. Esenin)

"Belaya beryoza"

Belaya beryoza

Pod moim oknom

Prinakrylas' snegom,

Tochno serebrom.

Na pushistyh vetkah

Snezhnoyu kajmoj

Raspustilis' kisti

Beloj bahromoj.

I stoit bereza

V sonnoj tishine,

I goryat snezhinki

$\mathrm{V}$ zolotom ogne.

A zarya, lenivo

Obhodya krugom,

Obsypaet vetki

Novym serebrom.

White is the color of Jesus, it carries purity and Holiness. The birch covered with snow, standing at the hut, in our opinion, is the brightest image of Russia. Pushkin's farewell to winter is associated with "pancakes":

.. Some of us thought no, and sorry winter woman,

And by spending it with pancakes and wine,

Wake her create ice cream and ice.

... Inoj v nas mysli net, i zhal' zimy staruhi,

I, provodiv ee blinami i vinom,

Pominki ej tvorim morozhenym i l'dom.

The pancakes symbolize the Pancake week, which is celebrated a week before the Great Post; commemorative feast, the funeral rites performed in memory of the deceased.

... Vot sever, tuchi nagonyaya, 
Dohnul, zavyl - i vot sama

Idet volshebnitsa zima.

Prishla, rassypalas'; klokami

Povisla na sukah dubov;

Legla volnistymi kovrami

Sredi polej, vokrug holmov;

Brega s nedvizhnoyu rekoyu

Sravnyala puhloj pelenoyu;

Blesnul moroz. I rady my

Prokazam matushki-zimy...

(A. S. Pushkin)

Here the North, scolding clouds,

Breathed, howled - and here is itself

There is a fairy winter.

Came, scattered; shreds

Hung on the boughs of oaks;

Lay wavy carpets

Among the fields, around the hills;

Banks, with a motionless river

Leveled a plump veil;

He flashed a cold.

Moreover, we are glad

Mother winter's leprosy...

For the formation of children consciously correct attitude to the nature, education of love for all living things, it is advisable to use poetry. Poems of Russian poets A. S. Pushkin, M. Yu. Lermontov, N. A. Nekrasov, F. I. Tyutchev, S. A. Yesenin contributes to the formation of children's interest in nature. Each poet in his own way presents the beauty and wonders of native nature, but the intent is the same and each author faces the following tasks: to form in young readers a careful attitude to nature, care for it; to develop moral and aesthetic susceptibility; to instill love for native nature; to educate humanity.

\subsection{The Dialogical Speech in Children's Poetry}

It is indisputable that the dialogical speech gives liveliness and energy to poetic texts. Therefore, dialogue between girlfriends raised about "whose mom is better and prettier?" with each read stanza is heated. As a result, without having come to a consensus and with the purpose, at last, to resolve "dispute", the girls address to the author of work:

- Kimni mamasy ariv?

- Kimni mamsy ehrshi? (Kerimova, 1989, p. 8)

- Whose mother is beautiful?

- Whose mother is ugly?

The author-observer finds a compromise, thereby resolving the situation:

Men ajtaman k"yzlag"a:

Ehriship turma ne bar? 
Analar bary ariv

Bary da syjly olar (Kerimova, 1989, p. 8).

I tell girls:

- Why do you argue so much?

All moms are beautiful

They are all honorable.

Children tend to take part in verbal competitions, to convince each other of their rightness, to prove their point of view. Children's dispute is harmless and does not bear any consequences. The poem "Whose mom is prettier" ("Kimni mamasy ariv?") of Vagit Ataev inspired by the subject and the story with the work of Dzh. Kerimova. However, unlike Dzh. Kerimova, Vagit Ataev otherwise resolves "the dispute" of girls because his characters address a question not to an adult, but to the neighbor's little boy who kept his head and childishly said:

\section{Sizinkinden kyop ariv}

Meni mamam ozok"da! (Ataev, 1987, p. 32)

Than yours, much more beautiful

My mother, of course!

The author correctly noticed the peculiarity of children's psychology: for each child his mother is the most beautiful and unique.

Poet writing for children has a huge responsibility. The little reader is imbued with unconditional trust, because he has not yet had time to learn all the difficulties of life inherent in the world of adults. Children are alien to criticism, they do not tend to analyze poetry, and they perceive everything as it is. Every new day for them is a small discovery, accompanied by bright emotions. The child is very sensitive: it is easy to offend and easy to amuse. He is unable to contemplate the tones and accepts only two primary colours - "white and black", and accordingly, antonymic pair relating to features of human nature: good and evil, right and wrong. The Russian literary critic V. G. Belinsky noted that "if you want to write for children, do not forget that they cannot think... Children's books should pass on to their young readers all not in worn-out maxims, not in cold morals, not in dry stories, but in narratives and pictures full of life and movement... warmed by the warmth of feeling, written in the language easy in its simplicity..." (Tokmakova \& Korkin, 1984, Feb., p. 7).

\section{Conclusions}

Thus, works of child lyrics of Dzhaminat Kerimova thematically and tonally are various. Observations of the poet for the life of kids, their characters, habits, interests allowed her to contemplate the world through the eyes of children. Optimism and cheerfulness of lyrical characters, fabulousness of poems, educating subtext, unexpected and entertaining ending, sound ingenuity, euphony - these are the main distinctive features of the poems of the poetess. It is worth emphasizing that their entertaining and informative content, contributing to the broadening of the horizons of children, developing their curiosity, insight, are a mandatory component that stimulates the development of their interests.

\section{References}

Adzhamatova, N. K. (1994). The emergence and development of Kumyk children's poetry (late XIX-first half of $X X$ century): Abstract of a Dissertation for the degree of Candidate of Philological Sciences. Makhachkala, 1994. $28 \mathrm{p}$.

Alkhlavova, I. Kh. (2018). The problem of the relationship between man and nature as one of the main reasons of lyrics of Dzhaminat Kerimova. The World of Science, Culture and Education, 2. 445-447.

Ataev, V. A. (1987). Sunflower (“Gyulajlan”). Makhachkala: Dagestan State Publishing House of Educational Pedagogical Literature, 54p.

Basko, N. V. (2014). Russian Proverbs and Sayings about Motherland as a reflection of national mentality (linguistic and methodological aspects). Bulletin of Novgorod State University n.a. Jaroslav Mudryi, 77, 57- 
59.

Belinskij, V. G., Chernyshevskij, N. G., \& Dobrolyubov, N. A. (1954). About children's literature: Collection of Articles. Moscow: Children's State Publishing House, p. 84.

Gul'cev, A. I. (2002). Modern children's literature of Great Britain: Historical and cultural aspects. Abstract of a Dissertation for the degree of Candidate of Cultural Sciences. Moscow, $206 \mathrm{p}$.

Kerimova, Dzh. (2008). A. Favorites (Sajlamly asarlary). Makhachkala: Dagestan State Publishing House, 528 p. Kerimova, Dzh. (1984). A. Lonely Rock (Ajry Yar). Makhachkala: Dagestan State Publishing House, 1984. 64 p.

Kerimova, Dzh. (1985). A. Sundial (Gyunsag'at). Makhachkala: Dagestan State Publishing House of Educational Pedagogical Literature, 1985. 28 p.

Kerimova, Dzh. (1986). A. The morning in Tarki (Targ"unu tangy). Makhachkala: Dagestan State Publishing House, $104 \mathrm{p}$.

Kerimova, Dzh. (1989). A. Winner-girl (Yarysh alg"an $\left.k^{\prime \prime} y z\right)$. Makhachkala: Dagestan State Publishing House of Educational Pedagogical Literature, $48 \mathrm{p}$.

Khadzhakaeva, A. M. (2018). Animalistic concept in Kumyk children's poetry of the XX century. The World of Science, Culture and Education, 6, 459-461.

Lojter, S. M. (2002). Russian children's literature of the XX century and children's folklore: problems of interaction: Abstract of a Dissertation for the degree of Candidate of Philological Sciences. Petrozavodsk, 41p.

Lyamova, B. Kh. (2013). Formation and development of Adygei children's literature: Dissertation for the degree of Candidate of Philological Sciences. Maykop, 2013. 158 p.

Mamaeva, S. M. (2018). Favorites: A collection of poetry (Sajlamly asarlary: shig'rulany zhyjymy). Махачкала: SAI RD "Dagestan book publishing house", $304 \mathrm{p}$.

Medzhidov, A. A. (1987). My yellow-mane. (Sariyalym). Makhachkala: Dagestan State Publishing House of Educational Pedagogical Literature, $96 \mathrm{p}$.

Meleksetyan, M. V. (2009). The image of mother in Russian poetry of the XX century: A. Blok, A. Akhmatova, A. Tvardovsky: Abstract of a Dissertation for the degree of Candidate of Philological Sciences - Moscow, $161 \mathrm{p}$.

Mukhamedova, F. Kh. (2001). Dagestan children's literature: historical and literary essay. Makhachkala: ILLA DSC RAS, $377 \mathrm{p}$.

Teliya, V. N. (1999). Reflexes of archetypes of consciousness in the cultural concept "Motherland". Slavic essays: a collection to mark the anniversary of S. M. Tolstoy: Moscow, Indrik Publ., 466-476.

Tokmakova, I., \& Korkin, V. (1984, Feb.). High art. Children's Literature, P. 7.

Valeev, M. Kh. (2002). Tatar children's literature and children's book of the end of XX century (1980-2000): Abstract of a Dissertation for the degree of Candidate of Philological Sciences. - Kazan', 47 p.

\section{Copyrights}

Copyright for this article is retained by the author(s), with first publication rights granted to the journal.

This is an open-access article distributed under the terms and conditions of the Creative Commons Attribution license (http://creativecommons.org/licenses/by/4.0/). 